\title{
CARDIOVASCULAR EFFECTS OF DROPERIDOL DURING ENFLURANE AND ENFLURANE - NITROUS OXIDE ANAESTHESIA IN MAN
}

\author{
ThEOdore H. STANLEY*
}

DROPERIDOL is not infrequently used as an amnesic supplement and an "after-load" reducer during anaesthesia in critically ill patients because of its reported benignity on myocardial dynamics. ${ }^{1.2}$ Although the cardiovascular effects of droperidol have been studied in combination with fentanyl and morphine, ${ }^{1-4}$ they have not been investigated when the drug is used during anaesthesia with potent inhalation agents. In this study we measured the cardiovascular effects of droperidol $5 \mathrm{mg}$ during light steady state enflurane-oxygen and enflurane-nitrous oxideoxygen anaesthesia in 20 patients undergoing cardiac or major vascular surgery.

\section{Merhods}

None of the patients were receiving betaadrenergic receptor blocking drugs, but four were taking digitalis preparations. Premedication included morphine $(5-10 \mathrm{mg})$, diazepam $(5-10$ $\mathrm{mg}$ ) and atropine $(0.3-0.5 \mathrm{mg})$ intramuscularly, 90 minutes before the scheduled operation. Prior to anaesthesia an intravenous infusion line was placed in an upper extremity, a central venous pressure catheter was placed percutaneously into the right atrium from the antecubital fossa or neck and a radial or brachial artery catheter was inserted percutaneously and threaded 30 to $72 \mathrm{~cm}$ into the central aorta. The aortic pressure catheter was attached through an arterial pressure transducer to a central digital computer substation in the operating room. Warner's method of analyzing the central aortic pulse-pressure curve was used to determine cardiac output ( $\dot{Q} \mathrm{r})$ heart rate (HR), stroke volume (SV), mean arterial blood pressure $(\overline{\mathrm{BP}})$ and peripheral arterial resistance (SVR). ${ }^{5}$

All patients had anaesthesia induced with sodium thiopentone, were paralyzed with suc-

* Theodore H. Stanley, M.D., Associate Professor of Anesthesiology/Surgery, Department of Anesthesiology, The University of Utah College of Medicine, Salt Lake City, Utah, 84132 .

Presented in part at the 1977 Annual Meeting of the Canadian Anaesthetists' Society, in Saskatoon, June 1977. cinylcholine, had their tracheas intubated and were mechanically ventilated with a volume limited respirator at volumes of 9 to $14 \mathrm{ml} / \mathrm{kg}$ and rates of 8 to 12 breaths/minute to maintain $\mathrm{PaCO}_{2}$ between 30 to 35 torr. Anaesthesia was maintained with enflurane one to two per cent and oxygen or enflurane 0.5 to 1.5 per cent, nitrous oxide 60 per cent and oxygen supplied from recently calibrated Ohio flowmeters. A semiclosed circle system provided carbon dioxide absorption and a total fresh gas inflow of 5-6 $1 / \mathrm{min}$. Muscle relaxation was maintained with pancuronium, $0.07 \mathrm{mg} / \mathrm{kg}$ intravenously initially and subsequent doses of 1 to $3 \mathrm{mg}$, as necessary.

Data were obtained at least $\mathbf{4 5}$ minutes after a steady state of anaesthesia was established during the operation. Periods chosen for data collection during the operation included those during which surgical stimulation was minimal and consistent. Recordings were made before and at 5-, 10 - and 15 -minute intervals after intravenous administration of droperidol $5 \mathrm{mg}$ during each of the anaesthetic techniques. Data were analyzed for significance using Student's t-test for paired data.

\section{RESULTS}

In ten patients receiving enflurane-nitrous oxide-oxygen anaesthesia, droperidol produced significant $(\mathrm{P}<0.025)$ decreases in $S V R$ and $\overline{\mathrm{BP}}$ and increases $(\mathrm{P}<0.05)$ in HR and $\dot{\mathrm{QT}}$ which were maximal after five minutes, somewhat less 5 minutes later and essentially back to control values 15 minutes following administration (Table I). SV was not significantly altered by droperidol during enflurane-nitrous oxide-oxygen at any time after administration. During enfluraneoxygen anaesthesia droperidol reduced SVR and $\overline{\mathrm{BP}}$ after five and ten minutes $(\mathrm{P}<0.05)$ but did not significantly alter any other variable measured (Table II). All variables were back to control levels 15 minutes after droperidol during enflurane-oxygen anaesthesia.

\section{Discussion}

Emphasis on preserving myocardial dynamics 
TABLE I

Cardiovascular Effects of Droperidol During ENFLURANCE-NITROUS OXIDE-OXYGEN ANESTHESIA $(\mathrm{MEAN} \pm \mathrm{SD})$

\begin{tabular}{lcccc}
\hline & & \multicolumn{3}{c}{ Minutes after droperidol } \\
\cline { 3 - 5 } & Control & 5 & 10 & 15 \\
\hline HR (beats/min) & 78 & $85^{*}$ & $83^{*}$ & 80 \\
& \pm 9 & \pm 8 & \pm 9 & \pm 11 \\
SV (ml) & 46 & 49 & 48 & 44 \\
& \pm 6 & \pm 5 & \pm 5 & \pm 6 \\
Q'T (1/min) & 3.6 & $4.2 *$ & 4.0 & 3.5 \\
& \pm 0.5 & \pm 0.4 & \pm 0.5 & \pm 0.7 \\
BP (torr) & 85 & $74 \dagger$ & $78^{*}$ & 83 \\
& \pm 7 & \pm 8 & \pm 7 & \pm 10 \\
SVR (PRU) & 20.8 & $16.5 \dagger$ & $17.9^{*}$ & 21.2 \\
& \pm 2.2 & \pm 1.9 & \pm 1.7 & \pm 1.8 \\
\hline
\end{tabular}

${ }^{*} P<0.05$, Student's paired t-test when compared to control values.

†P $<0.025$, Student's paired $t$-test when compared to control values.

TABLE II

Cardiovascular Effects of Droperidol during Enflurane-Oxygen Anesthesia (Mean \pm SD)

\begin{tabular}{lcccc}
\hline \hline & \multicolumn{4}{c}{ Minutes after droperidol } \\
& Control & 5 & 10 & 15 \\
\hline HR (beats/min) & 81 & 83 & 84 & 81 \\
& \pm 8 & \pm 7 & \pm 7 & \pm 9 \\
SV (m) & 52 & 55 & 53 & 49 \\
& \pm 8 & \pm 6 & \pm 9 & \pm 7 \\
Qr (1/min) & 4.2 & 4.6 & 4.4 & 4.0 \\
& \pm 0.6 & \pm 0.5 & \pm 0.4 & \pm 0.6 \\
BP (torr) & 95 & $87^{*}$ & $88^{*}$ & 93 \\
& \pm 6 & \pm 8 & \pm 5 & \pm 9 \\
SVR (PRU) & 18.8 & $16.9^{*}$ & $17.4^{*}$ & 19.2 \\
& \pm 1.9 & \pm 2.1 & \pm 1.8 & \pm 1.9 \\
\hline
\end{tabular}

* $\mathbf{P}<0.05$, Student's paired $t$-test when compared to control values.

in modern anaesthesia, especially in patients with cardiac disease, has supported the concept of "light" anaesthesia. ${ }^{6}$ One complication of this approach has been hypertension during operation. ${ }^{7.8}$ Hypertension during operation increases myocardial oxygen demand and can upset the delicate balance of myocardial oxygen supply and myocardial oxygen demand in patients with coronary artery disease. ${ }^{9}$ As a result, the use of vasodilators, ganglionic blockers or other compounds that reduce or preserve $\overline{\mathrm{BP}}, \mathrm{SVR}$ and left ventricular "after-load" has become popular, especially in patients with coronary artery disease. ${ }^{10-12}$ However, many of these compounds also reduce $\mathrm{QT}$ while reducing $\overline{\mathrm{BP}}$ and SVR and some have potential toxic side effects as well. ${ }^{11-t 3}$

The results of this study demonstrate that small amounts of intravenous droperidol produce a significant, though relatively transient, reduction in $\overline{\mathrm{BP}}$ and SVR during enflurane-nitrous oxide-oxygen and enflurane-oxygen anaesthesia which is associated with an increase or no change in QT. Similar changes have also been found when droperidol is employed during halothane (Stanley, unpublished data) or morphine anaesthesia. ${ }^{1}$ These data suggest that droperidol causes minimal or no myocardial depression when used during potent inhalation or narcotic anaesthesia. Since droperidol has significant amnesic properties, our findings also suggest that the compound is an excellent supplement and short acting "afterload" reducer during light anaesthesia with potent inhalation or narcotic anaesthesics.

Although large doses of droperidol ( $1 \mathrm{mg} / \mathrm{kg}$ ) have been shown to impair left ventricular contractility in right-heart bypass preparations in the dog, smaller doses $(0.5 \mathrm{mg} / \mathrm{kg})$ do not influence myocardial dynamics in this model or in intact dogs. ${ }^{4.14}$ Kreuscher ${ }^{15}$ showed that droperidol 20 $\mathrm{mg}$ intravenously does not influence myocardial contractility in human volunteers. A recent report by Ferrari, Gorten, Talton, Canent and Goodrich ${ }^{3}$ found that droperidol $5 \mathrm{mg}$ produced a dramatic ( +47 per cent) increase in QT, a similar increase in $\mathrm{SV}$ and no significant change in $\overline{\mathrm{BP}}$ in healthy, unanaesthetized human volunteers. All the changes these authors found were transient and all dynamics had returned to control values within 17 minutes.

It has been suggested that the mechanism by which droperidol increases cardiac output is mild alpha-adrenergic blockade. ${ }^{16}$ Significant reductions in SVR ${ }^{1-3.16}$ after its use in all previous investigations are compatible with this suggestion. In this study, our patients anaesthetized with enflurane-nitrous oxide-oxygen anaesthesia had control SVR values that were significantly $(P<$ $0.05)^{*}$ higher than those anaesthetized with enflurane-oxygen and, as a result, the former experienced greater reductions in SVR and increases in $\mathrm{Q} T$ after droperidol. These findings are exactly what would be expected if the primary circulatory action of droperidol was mild alphaadrenergic blockade. However, if this were the case, SV should also have increased more in the

\footnotetext{
*Using Student's t-test for unpaired groups.
} 
patients anaesthetized with enflurane-nitrous oxide-oxygen than in those given enfluraneoxygen. There was, however, no difference in the SV response of the two groups to the compound. Indeed, SV was only mildly and not significantly increased in either group. Rather, HR was increased after droperidol in the patients anaesthetized with enflurane-nitrous oxideoxygen, and unchanged in those given enflurane-oxygen. Increases in $H R$ have been found after droperidol by Ferrari and coworkers ${ }^{3}$ in unanaesthetized human volunteers as well as by us in patients anaesthetized with large doses of morphine and oxygen and given droperidol as a supplement. ${ }^{1}$ The mechanism of this change and the reason for its occurrence in this study in the presence of nitrous oxide but not in its absence is unclear. Perhaps droperidol produces mild vagal blockade in certain situations. Volunteers and patients given droperidol plus fentanyl do not usually experience a change in HR in the absence of surgical stimulation. ${ }^{2,3}$ This could be due to the well known central vagal stimulating properties of fentanyl blocking ability of droperidol to increase HR. ${ }^{17}$ On the other hand, droperidol, when employed during certain anaesthetic techniques may result in some myocardial depression which causes a reflex increase in HR. SV would not necessarily be reduced in the latter situation because of a simultaneous reduction in SVR. Unfortunately our data in this experiment are inadequate to prove or disprove either of these theories.

\section{SUMmaRY}

The cardiovascular effects of intravenous droperidol $5 \mathrm{mg}$ were measured in 20 patients during steady state enflurane-nitrous oxideoxygen or enflurane-oxygen anaesthesia. During enflurane-nitrous oxide-oxygen anaesthesia, droperidol produced significant decreases in SVR and $\overline{\mathrm{BP}}$ and increases in $\mathrm{HR}$ and $\dot{Q} \mathrm{~T}$ which were maximal after five minutes, somewhat less five minutes later, and back to control values 15 minutes after administration. SV was not significantly altered by droperidol during enflurane-nitrous oxide-oxygen at any time after administration. During enflurane-oxygen anaesthesia droperidol reduced SVR and $\bar{B} \bar{P}$ after five and ten minutes but did not significantly alter any other variable. All variables had returned to control levels 15 minutes after droperidol during enflurane-oxygen anaesthesia. These data dem- onstrate that droperidol produces a significant though transient reduction of $\overline{\mathrm{BP}}$ and SVR during enflurane anaesthesia which is associated with no change or an increase in $\dot{Q}$. Our findings suggest that droperidol causes minimal or no myocardial depression when used during potent inhalation anaesthesia and may have a place as an amnesic supplement and/or "afterload" reducer during light enflurane anaesthesia.

\section{RÉSUMÉ}

La diminution de la post-charge secondaire à l'administration intraveineuse de $5 \mathrm{mg}$ de droperidol a été étudiée chez 20 malades au cours d'anesthésies légères et bien établies à l'enflurane-oxygène ou à l'enflurane-protoxyde-oxygène. La fréquence cardiaque, le volume d'éjection, le débit cardiaque, la pression artérielle moyenne ainsi que la résistance artérielle périphérique ont été mesurés 5,10 et 15 minutes après l'administration du dropéridol, ceci au moyen de la méthode de Warner (analyse par ordinateur de la courbe de pression aortique). Sous anesthésie à l'enflurane-protoxyde-oxygène, l'administration du dropéridol était suivie d'une diminution significative $(p<0.025)$ de la résistance vasculaire périphérique et d'une augmentation significative $(p<0.05)$ de la fréquence et du débit cardiaque; ces changements étaient à leur maximum cinq minutes après l'injection, un peu moins marqués cinq minutes plus tard avec retour au $x$ valeurs-contrôles 15 minutes après l'injection. Le volume d'éjection n'était pas modifié de façon significative.

Avec le mélange enflurane-oxygène, on observait, 5 et 10 minutes après l'administration du dropéridol, une diminution $(p<0.05)$ de la résistance périphérique et de la pression artérielle moyenne, mais les autres paramètres n'étaient pas modifiés de façon significative. Tous les résultats étaient de retour aux valeurs-contrôles 15 minutes après l'injection.

Notre étude démontre que sous anesthésie à l'enflurane, le dropéridol produit une diminution transitoire mais significative de la pression artérielle moyenne et de la résistance périphérique, avec un débit cardiaque inchangé ou augmenté. Les chiffres obtenus indiquent que sous anesthésie à l'enflurane, le dropéridol ne cause que très peu ou pas de dépression myocardique. Comme ce médicament possède des propriétés amnésiques significatives, il constitue un excellent supplément à une anesthésie légère à 
l'enflurane ainsi qu'à d'autres anesthésiques d'inhalation, tout en permettant une brève réduction de la post-charge.

\section{REFERENCES}

1. Stanley, T.H., BennetT, G.M., Loeser, E.A., Kawamura, R., \& SentKer, C.R. Cardiovascular effects of diazepam and droperidol during morphine anesthesia. Anesthesiology 44: 255 (1976).

2. Sroelting, R.K., Gibis, P.S., Creasser, C.W. \& Peterson, C. Hemodynamic and ventilatory responses to fentanyl, fentanyl-droperidol, and nitrous oxide in patients with acquired valvular heart disease. Anesthesiology 42: 319 (1975).

3. Ferrari, H.A., Gorten, R.J., Talton, I.H., Cannet, R., \& Goodrich, J.K. The action of droperidol and fentanyl on cardiac output and related hemodynamic parameters. South. Med. J. 67: 49 (1974).

4. Ostheimer, G.W., Shanahan, E.A., Guyton, R.A., DaggetT, W.M., \& Lowenstein, E. Effects of fentanyl and droperidol on canine left ventricular performance. Anesthesiology 42: 288 (1975).

5. Warner, H.R., Gardner, R.M., \& Toronto, A.F. Computer-based monitoring of cardiovascular functions in post-operative patients. Circulation 27 (S2) II: 68 (1968)

6. Hamilton, W.K. Do let the blood pressure drop and do use myocardial depressants. Anesthesiology 45: 273 (1976).

7. Estafanous, F.G., Tarazi, R.C., Viljoen, J.F., \& EL TAWIL, M.Y. Systemic hypertension follow- ing myocardial revascularization. Am. Heart J. 85 732 (1973).

8. Arens, J.F., Bendow, B.P., \& Ochsner, J.L. Morphine anesthesia for aorto-coronary bypass procedures. Anesth. Analg. 51: 901 (1972).

9. Braunwald, E. Control of myocardial oxygen consumption: Physiologic and clinical considerations. Am. J. Cardiol, 27: 416 (1971).

10. Kaplan, J.A., Dunbar, R.W., \& Jones, E.L Nitroglycerin infusion during coronary artery surgery. Anesthesiology 45: 14 (1976).

11. TAYlor, T.H., Styles, M., \& Lamming, A.J. Sodium nitroprusside as a hypotensive agent in general anesthesia. Br. J. Anesth. 42: 859 (1970).

12. Jordan, W.S., Grayes, C.L., Ueda, I., \& Roberts, $T$. Cardiovascular effects of three techniques for inducing hypotension during anesthesia. Anesth. Analg. 50: 1059 (1971).

13. Tinker, J.H. \& Michenfelder, J.D. Sodium nitroprusside: pharmacology, toxicology and therapeutics. Anesthesiology 45: 340 (1976).

14. Gemperle, M. \& Moret, P. L'influence du fentanyl sur le systeme cardio-vasculaire. Ann. Anesth. Franc. 9: 333 (1968).

15. KREUSCHER, $\mathrm{H}$. The action of dehydrobenzperidol on the cardiovascular system in man. ActaAnaesthesiol. 9: 155 (1965).

16. Whitman, J.G. \& Russel, W.J. The acute cardiovascular changes and adrenergic blockade by droperidol in man. Br. J. Anaesth. 43: 581 (1971).

17. Gardocki, J.F. \& Yelnosky, J. A study of some of the pharmacologic actions of fentanyl citrate. Toxicol. Appl. Pharmacol. 6: 48 (1964) 